\title{
IDENTIFIKASI KELAYAKAN JEMBATAN BATANGHARI II KOTA JAMBI MENGGUNAKAN MIKROTREMOR DENGAN METODE HORIZONTAL TO VERTICAL SPECTRAL RATIO (HVSR)
}

\author{
Oky Dwi Syaputra ${ }^{1, *}$, Faizar Farid ${ }^{2}$, Samsidar $^{1}$, Linda Handayani $^{1}$ \\ ${ }^{1}$ Program Studi Fisika, Fakultas Sains dan Teknologi, Universitas Jambi \\ ${ }^{2}$ Program Studi Kimia, Fakultas Sains dan Teknologi Universitas Jambi \\ *E-mail korespondensi: okysyaputra03@gmail.com
}

\begin{abstract}
The feasibility study of Batanghari II Bridge with the value of natural frequency of Bridge using microtremor has been done. The purpose of this research is to know the bridge's natural frequency value using Horizontal to Vertical Spectral Ratio (HVSR) method and to know the relatif damage to Bridge. In this study Bridge as an object because, Bridge is an alternative way that connects one place with another place separated by a river or ditch which is often used by society for activity. To get the bridge's natural frequency value using Microtremor sensor which is directly placed bridged with geopsy software to process its data and using HVSR method. The result of this research is the natural bridge frequency value of $7.40441 \mathrm{~Hz}$. To determine the feasibility of the bridge compared with the standard value of the bridge frequency of 7,675 $\mathrm{Hz}$ and stated the state of the Batanghari II bridge is still intact from the structural and the natural frequency value of the soil on the bridge buffer of $12.7489 \mathrm{~Hz}$ and $13.6343 \mathrm{~Hz}$ that the soil type is older soil. Can be said the foundation of the bridge last long.
\end{abstract}

Keywords: Bridge, frequency, microtremor, HVSR method

\section{ABSTRAK}

Telah dilakukan penelitian kelayakan Jembatan Batanghari II dengan nilai frekuensi alami Jembatan menggunakan mikrotremor. Tujuan dari penelitian ini adalah mengetahui nilai frekuensi alami jembatan menggunakan metode Horizontal to Vertical Spectral Ratio (HVSR) serta mengetahui kerusakan relatif atas Jembatan. Pada penelitian ini Jembatan sebagai objek karena, Jembatan merupakan jalan alternatif yang menghubungkan satu tempat dengan tempat lain yang dipisahkan oleh suatu sungai ataupun parit yang sering digunakan masyarakat untuk beraktifitas. Untuk mendapatkan nilai frekuensi alami jembatan menggunakan sensor Mikrotremor yang langsung diletakan dijembatan dengan software geopsy untuk mengolah datanya serta menggunakan metode HVSR. Hasil dari penelitian ini berupa nilai frekuensi alami jembatan sebesar $7.40441 \mathrm{~Hz}$. Untuk menentukan kelayakan jembatan dibandingkan dengan nilai standar frekuensi jembatan sebesar $7.675 \mathrm{~Hz}$ dan dinyatakan keadaan jembatan Batanghari II masih utuh dari strukturalnya serta nilai frekuensi alami tanah pada penyangga jembatan sebesar $12.7489 \mathrm{~Hz}$ dan $13.6343 \mathrm{~Hz}$ bahwa jenis tanah tersebut merupakan tanah yang lebih tua. Dapat dikatakan pondasi jembatan tersebut bertahan lama.

Kata kunci: jembatan,frekuensi, mikrotremor, metode HVSR.

\section{PENDAHULUAN}

Jembatan merupakan jalan alternatif yang menghubungkan satu tempat dengan tempat lain yang dipisahkan oleh suatu sungai ataupun parit. Dengan begitu perannya sangat menguntungkan bagi masyarakat karena tidak menyusahkan untuk berjalan jauh. Maka dari itu pembuatannya harus diperhatikan agar tidak mudah rusak, hancur, atau terjadi sesuatu yang tidak diinginkan.
Dalam pembuatan jembatan ada beberapa hal yang harus diperhatikan seperti lokasi dan lingkungannya. Setelah diketahui jenis tanah dengan jenis batuan dasar yang terletak dibawah permukaan, bahan-bahan yang digunakan harus lulus uji kekuatan ataupun ketahanan untuk membuat suatu jembatan tersebut layak digunakan. Bahan yang digunakan harus sesuai dengan Standar Nasional Indonesia (SNI). Selain faktor-faktor tersebut, jembatan yang layak juga harus lulus uji. Ada beberapa uji yang bisa dilakukan untuk mengetahui kekuatan jembatan, 
salah satunya adalah uji getaran. Cara uji getar lebih ekonomis dan tidak merusak struktur, dibandingkan dengan cara uji pembebanan [1].

Metode HVSR merupakan metode yang digunakan sebagai indikator struktur bawah permukaan tanah yang memperlihatkan hubungan antara rasio spektrum fourier dari sinyal mikrotremor komponen horizontal terhadap komponen vertikalnya [2]. Beberapa penelitian sebelumnya mengenai mikrotremor menggunakan metode HVSR Yaitu: pertama, dengan meperhitungkan faktor amplifikasi tanah yang berada pada daerah yang memiliki potensi gempa dengan menggunkan metode HVSR begitu relevan untuk dilakukan, karena hasil yang didapatkan merupakan nilai frekuensi dominan yang akan dilihat dengan puncakpuncak frekuensi berupa grafik [3]. Mengolah data mikrotremor dengan HVSR menggunkan Matlab yaitu dengan memetakan nilai frekuensi dominan yang didapat [4]. Analisia mikrotremor dengan menggunakan metode HVSR untuk pemetaan Mikrozonasi suatu wilayah yang terdapat potensi gempa bumi dengan mengetahui kerentanan tanah tersebut [5]. Oleh karena itu peneliti tertarik untuk melakukan penelitian menggunakan mikrotremor dengan metode HVSR untuk menentukan kelayakan Jembatan Batanghari II Kota Jambi.

\section{METODE PENELITIAN}

\section{Tempat dan Waktu}

Penelitian ini dilakukan di kawasan Jembatan Batanghari II Kota Jambi, jalan Jembatan Batanghari II, Tj. Johor, Kecamatan Pelayangan, Kota Jambi, Jambi. Waktu penelitian ini dalam pengambilan data dilakukan selama 8 hari dari tanggal 3 - 10 Mei 2018.

\section{Alat dan Bahan Penelitian}

Alat yang digunakan dalam penelitian ini yaitu: mikrotremor Untuk merekam getaran, seismograf MAE 6000, GPS, bateray 12 volt, kabel, laptop, pena, log book, dan kamera.

\section{Survey Lokasi}

Sebelum melakukan pengambilan data lapangan maka dilakukan survei dengan melakukan kunjungan ke lokasi penelitian. Survei lokasi penelitian bertujuan untuk mengetahui kondisi daerah yang diteliti mulai dari morfologi, lingkungan dan kondisi jembatan.

\section{Akuisi Data}

Akuisisi data merupakan proses pengambilan data. Akuisisi data pada penelitian ini dilakukan dengan pengambilan data gelombang. Dengan mendapatkan gelombang yang dihasilkan dari mikrotremor serta dengan alat pendukung lainnya.

\section{Pengolahan Data}

Prosedur pengolahan data dimulai dengan menginput nilai yang didapatkan dari lapangan kedalam Microsoft Excel dengan format xlc. Data dalam Microsoft Excel tersebut akan digunakan untuk analisis data dengan software Geopsy menggunkan metode HVSR dengan langkah ratio $\mathrm{H} / \mathrm{V}$.

\section{Analisis Data}

Tahap analisis data dapat dilakukan dengan melakukan picking data gelombang yang dihasilkan dari mikrotremor dengan mengambil gelombang yang stabil. Setelah tahap picking selesai maka dilanjutkan tahap hubungan antara horizontal (east-west), horizontal (nort-south), dan vertikal. Lalu dilanjutkan dengan menganalisis hasil grafik yang dihasilkan anatar hubungan horizontal vertikal dengan frekuensi.

\section{HASIL DAN PEMBAHASAN}

\section{Proses Menentukan Nilai Frekuensi Alami}

1. Melakukan picking (memilih) data gelombang.

Untuk melakukan picking peneliti harus teliti dengan hasil gelombang yang didapatkan agar hasil yang picking yang dilakukan berhasil. Picking yang dilakukuan yaitu dengan menentukan gelombang yang dihasilkan stabil atau konstan dan lebih mudahnya dengan melihat log book yang dibuat. 


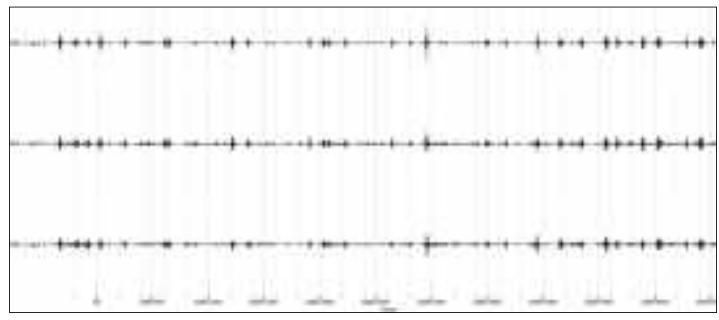

(a)

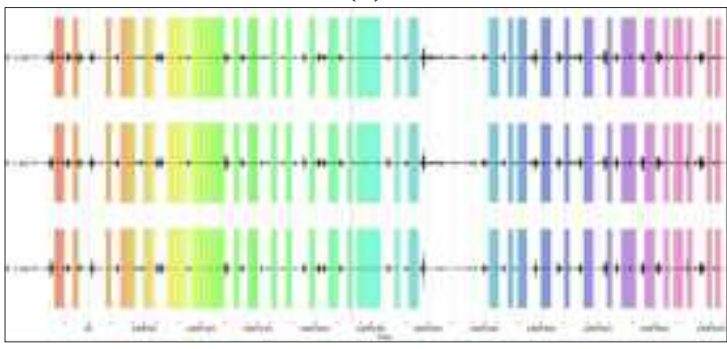

(b)

Gambar 1. Hasil picking data lapangan.(a) data lapangan,(b) hasil picking lapangan.

\section{Melakukan filtering}

Filtering adalah upaya untuk memisahkan nilai frekuensi yang diinginkan dari gelombang seismik dan membuang yang tidak diinginkan. Filter tersebut dilakukan untuk melihat nilai frekuensi yang masih mendominasi nilai yang besar ataupun yang rendah dengan cara filtering dengan jenis-jenis yang diatas untuk meminimalisir nilai-nilai frekuensi yang didapatkan setelah dilakukan picking.

3. Melihat hasil grafik pada kurva $\mathrm{H} / \mathrm{V}$

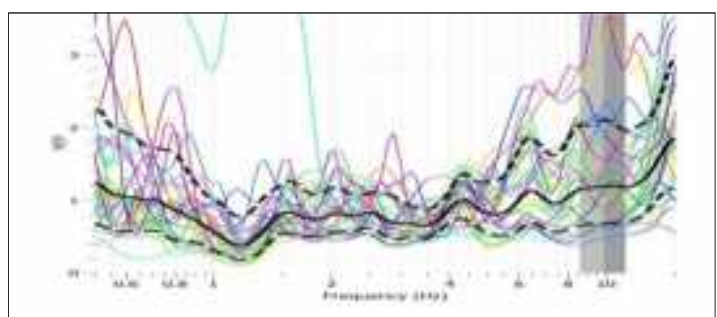

(a)

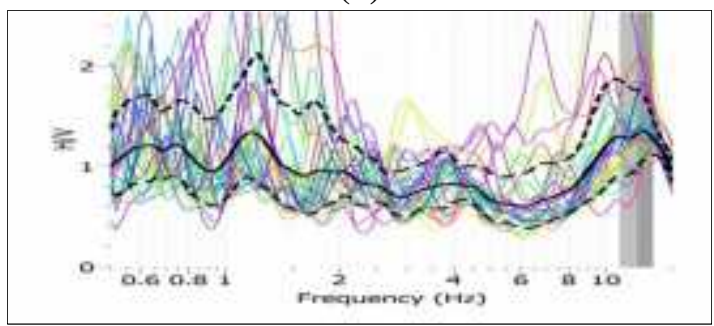

(b)

Gambar 2. Data frekuensi alami titik 1. (a) arah barat, (b)arah timur.
Grafik ini dapat dilihat setelah dilakukannya tahap picking, grafik ini belum dikatakan benar sebelum dilakukan filtering. Grafik ini dapat dikatakan benar atau salah dengan melihat nilai standart deviasi (garis putus-putus) yang terdapat pada grafik yang bagian atas dan bagian bawahnya mendekati atau menajuh dengan nilai rata-rata HVSR (garis lurus) yang berada di tengah-tengah nilai standar deviasi. Hasil penelitian dapat diilihat pada Gambar 2, 3, 4, 5, 6,7 .

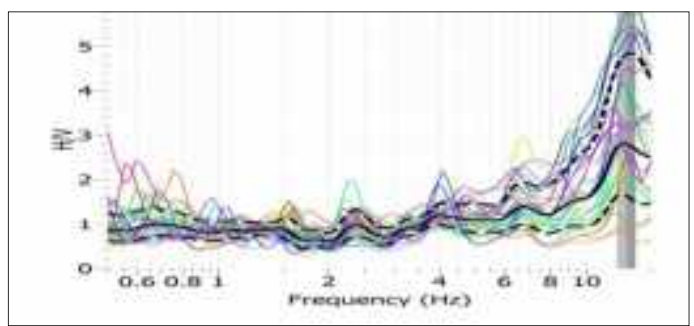

(a)

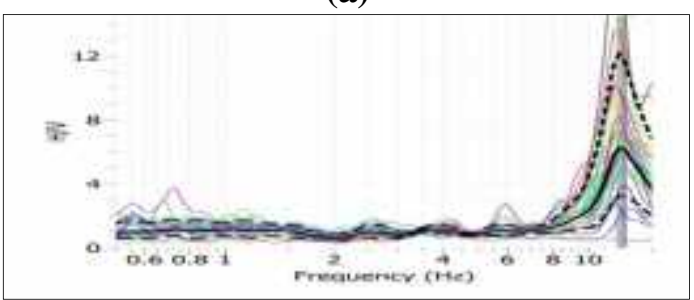

(b)

Gambar 3. Data frekuensi alami titik 2. (a) arah barat, (b)arah timur.

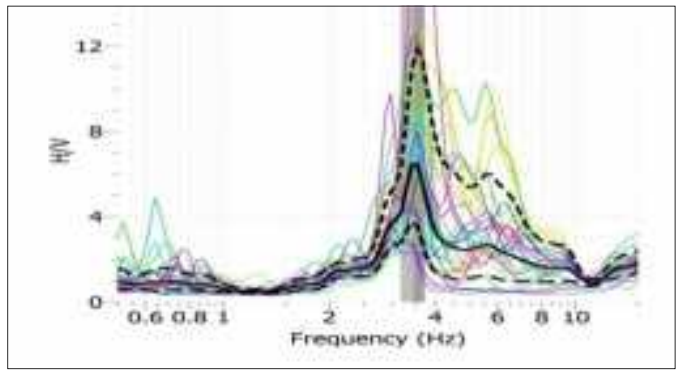

(a)

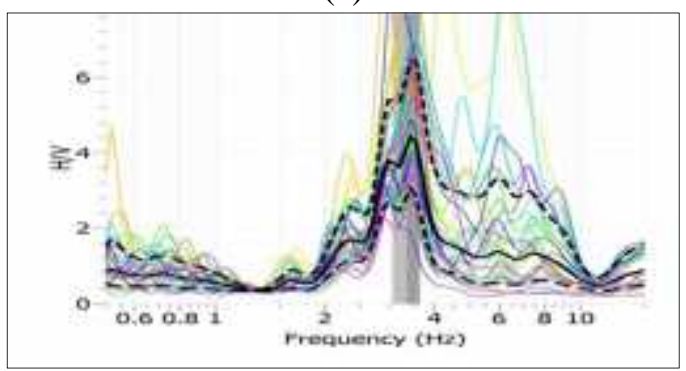

(b)

Gambar 4. Data frekuensi alami titik 3. (a) arah barat, (b)arah timur. 


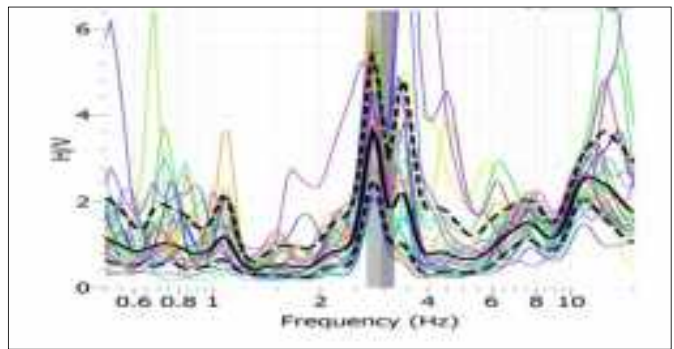

(a)

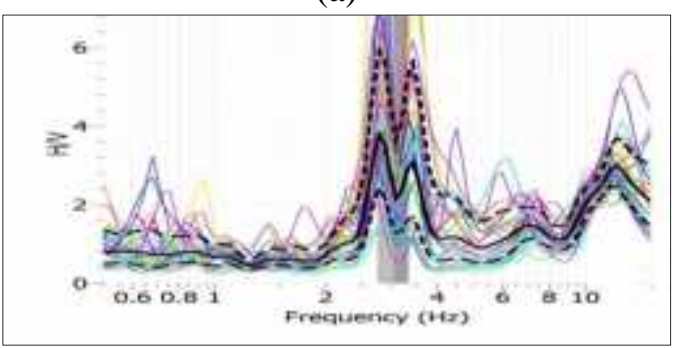

(b)

Gambar 5. Data frekuensi alami titik 4. (a) arah barat, (b)arah timur.

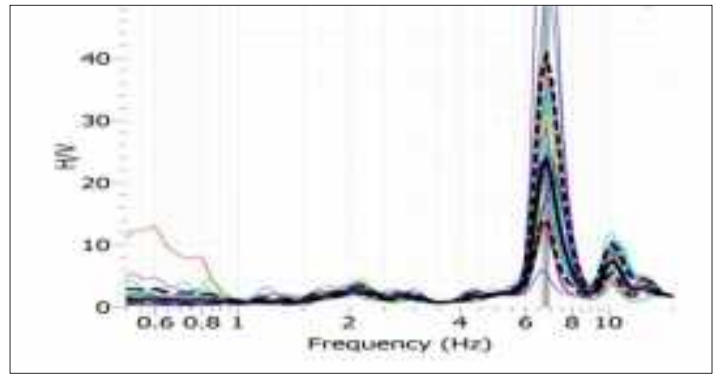

(a)

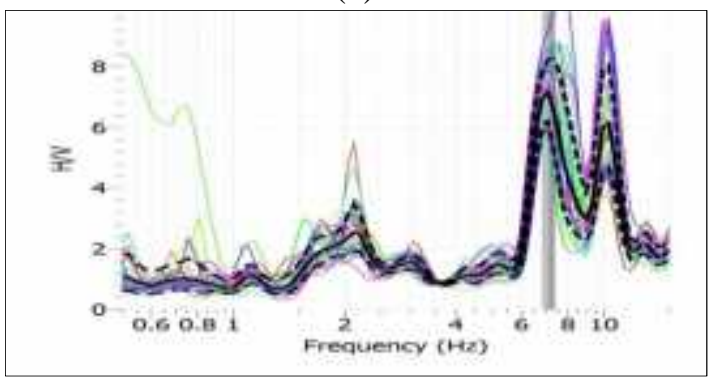

(b)

Gambar 6. Data frekuensi alami titik 5. (a) arah barat, (b)arah timur.

Berdasarkan Gambar 2, 3, 4, 5, 6, dan 7 nilai frekuensi alami ditunjukan pada bentuk bar berwarna abu-abu yang terdapat pada grafik HVSR. Bentuk grafik yang dihasilkan sesuai dengan keadaan di lapangan. Semakin sepi keadaan jalan maka grafik yang dihasilkan akan membentuk satu puncak yang tinggi dan tidak ada data frekuensi yang tidak beraturan.
Nilai frekuensi disebabkan dengan terjadinya besar getaran yang dihasilkan oleh jembatan. Nilai frekuensi yang terjadi di daerah tengah jembatan lebih kecil dibandingkan di pangkal dan di ujung jembatan karena formasi keaadaan jembatan yang padat dan tidak renggang. Sedangkan bagian tengah memiliki keadaan yang renggang. Dan getaran yang dihasilkan pada keadaan jembatan bagian ujung dan pangkal tidak begitu besar dibandingkan dengan jembatan bagian tengah.

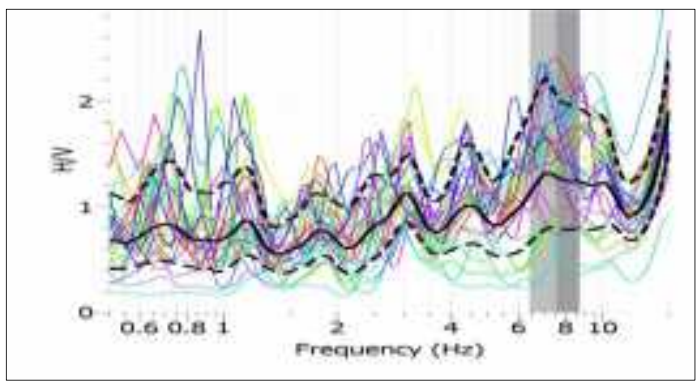

(a)

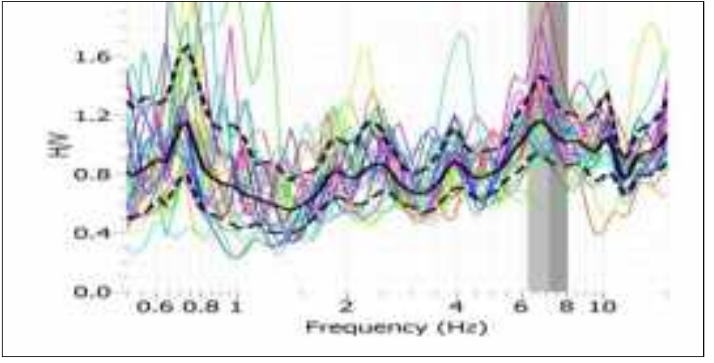

(b)

Gambar 7. Data frekuensi alami titik 6. (a) arah barat, (b)arah timur.

Tabel 1. Nilai frekuensi alami Jembatan batanghari II.

\begin{tabular}{ccc}
\hline Lintasan & Titik & $\begin{array}{c}\text { Frekuensi } \\
\text { alami }(\mathbf{H z})\end{array}$ \\
\hline \multirow{2}{*}{1} & Barat & 9.9111 \\
& Timur & 12.1329 \\
2 & Barat & 12.8966 \\
\multirow{2}{*}{3} & Timur & 12.5014 \\
& Barat & 3.45748 \\
4 & Timur & 3.35074 \\
\multirow{2}{*}{5} & Barat & 2.95111 \\
& Timur & 3.04643 \\
\multirow{2}{*}{6} & Barat & 6.79248 \\
& Timur & 7.10636 \\
\hline \multicolumn{2}{|c}{ Frekuensi jembatan } & 7.56923 \\
\hline
\end{tabular}




\section{Kelayakan Jembatan}

Tabel 2. Nilai kerusakan relatif.

\begin{tabular}{cccccc}
\hline Lintasan & Titik & $\begin{array}{c}\text { Frekuensi } \\
\text { alami } \\
\text { Jembatan }(\mathrm{Hz})\end{array}$ & $\begin{array}{c}\text { Rata-rata } \\
\text { frekuensi } \\
\text { Jembatan } \\
(\mathrm{Hz})\end{array}$ & $\begin{array}{c}\text { Frekuensi } \\
\text { teoritis }(\mathrm{Hz})\end{array}$ & $\begin{array}{c}\text { Kerusakan } \\
\text { relatif }\end{array}$ \\
\hline 1 & Barat & 9.9111 & & & \\
& Timur & 12.1329 & & & \\
2 & Barat & 12.8966 & & & \\
& Timur & 12.5014 & & & \\
3 & Barat & 3.45748 & & & \\
& Timur & 3.35074 & 7.654 & \\
4 & Barat & 2.95111 & & & \\
& Timur & 3.04643 & & & \\
5 & Barat & 6.79248 & & & \\
& Timur & 7.10636 & & & \\
\hline
\end{tabular}

Berdasarkan Tabel 2 peneliti mengetahui keadaan Jembatan Batanghari II. Nilai kerusakan relatif Jembatan Batanghari II sebesar $3.53 \%$. Berdasarkan nilai tersebut dapat dinyatakan bahwa Jembatan Batanghari II dalam keadaan yang utuh/baik.

\section{Jenis Tanah pada Jembatan}

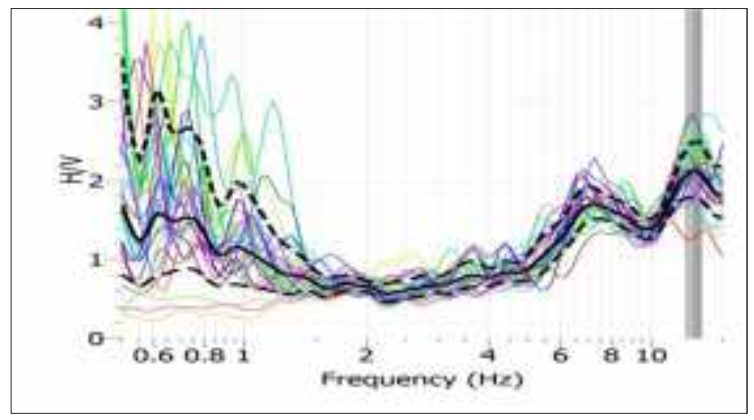

(a)

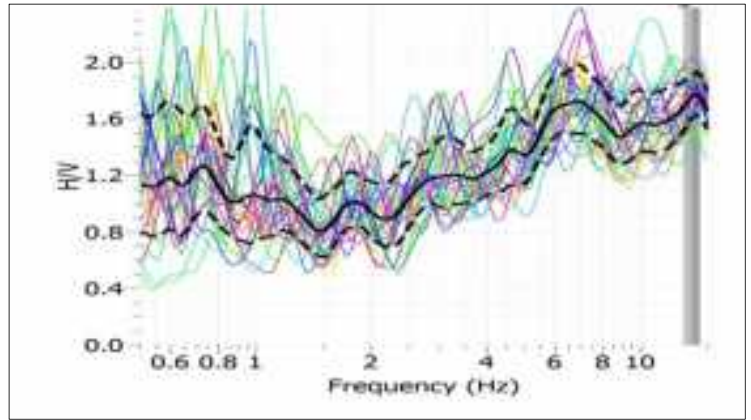

(b)

Gambar 8. Data frekuensi alami tanah, (a). dekat penyengga 1 , (b) dekat penyangga 2 .
Dalam penentuan pondasi untuk sebuah bangunan dapat dilihat dengan melihat jenis bawah permukaan tanah. untuk melihat nilai frekuensi tanah dapat dilihat pada Gambar 8.

Berdasarkan Gambar 8 nilai frekuensi alami tanah disekitar jembatan Batangharai II pada penyangga 1 adalah $12.7489 \mathrm{~Hz}$ dan penyangga 2 adalah 13.6343 Hz. Dapat dikatakan secara literatur pada Tabel 1 jenis tanah pada Jembatan Batanghari II termasuk kedalam klasifikasi tanah jenis 1 yang kondisi tanahnya merupakan batuan tersier atau yang lebih tua terdiri dari batuan hard sandy dan gravel.

Selain dengan jenis tanah untuk menentukan kelayakan pondasi yang dibuat nilai frekuensi alami juga dapat menentukan kelayakan pondasi. Nilai frekuensi jembatan harus lebih kecil dibandingkan dari nilai frekuensi tanah agar jembatan tidak mengalami rusak berat maupun dapat mengalami jembatan runtuh.

\section{KESIMPULAN}

Berdasarkan penelitian yang telah dilakukan dapat disimpulkan sebagai berikut: Setelah dilakukan pengambilan data secara alami di Jembatan dengan menggunakan metode HVSR 
dinyatakan nilai Jembatan Batanghari II sebesar 7.40441 $\mathrm{Hz}$ hasil dari rata-rata nilai frekuensi yang dilakukan dengan 6 lintasan yang memiliki 12 titik penelitian nilai frekuensinya sebesar: $9.9111 \mathrm{~Hz}, 12.1329 \mathrm{~Hz}, 12.8966 \mathrm{~Hz}, 12.5014$ $\mathrm{Hz}, 3.45748 \mathrm{~Hz}, 3.35074 \mathrm{~Hz}, 2.95111 \mathrm{~Hz}$, $3.04643 \mathrm{~Hz}, 6.79248 \mathrm{~Hz}, 7.10636 \mathrm{~Hz}, 7.56923$ $\mathrm{Hz}$, dan $7.13705 \mathrm{~Hz}$. Setelah didapatkan nilai frekuensi Jembatan dapat diketahui kelayakan dengan melihat persentase nilai relatif. Nilai relatif Jembatan Batanghari II sebesar $3.53 \%$ dan dinyatakan bahwa Jembatan dalam keadaan utuh strukturnya.

\section{SARAN}

Penelitian lebih lanjut disarankan mengecilkan jarak pengukuran agar data yang dihasilkan lebih bagus. Penelitian lebih lanjut lebih baik memilih tempat yang rawan bencana seperti: tanah lonsor, gempa bumi dan yang lain serta menggunakan metode yang berbeda.

\section{DAFTAR PUSTAKA}

1. Departemen Pekerjaan Umum. (2002). Penilaian Kondisi Jembatan untuk Bangunan Bawah dengan Cara Uji Getar. Jakarta: Yayasan Badan Penerbit PU.
2. Nakamura, Y. (1989). A Method For Dynamic Characteristics Estimation Of Subsurface Using Microtremor on the Ground Surface, Tokyo: Quatrely Reports of the Railway Technical Research Institute.

3. Partono, W., Masyur, I., Sri, P. R., \& Syamsul, M. (2013). Aplikasi Metode HVSR pada Perhiungan Faktor Amplifikasi Tanah di Kota Semarang, Jurnal Ilmu dan Terapan Bidang Teknik Sipil, 19(2).

4. Yuliawati, W. S. (2017). Pengolahan Data Mikrotremor Berdasarkan Metode HVSR dengan Menggunakan Matlab, Skripsi. Lampung: Universitas Lampung.

5. Harahap, R. A. P, Fatmawati, L. E, Soemitro, R. A. A, \& Satrya, T. R. (2013). Analisis Mikrotremor Dengan Metode HVSR (Horizontal to Vertical Ratio) Untuk pemetaan Mikrozonasi di Kelurahan Kejawan Putih Tambak Surabaya, Jurnal Teknik Pomits, 1(1). 